\title{
Relationship between polymorphism of receptor SCARB2 gene and clinical severity of enterovirus-71 associated hand-foot-mouth disease
}

\author{
Xia Wang ${ }^{\dagger}$, Hong Liu', Ying Li', Rui Su*, Yamin Liu and Kunyan Qiao
}

\begin{abstract}
Background: To investigate the relationship between polymorphism of scavenger receptor class B member 2 (SCARB2) gene and clinical severity of enterovirus (EV)-71 associated hand-foot-mouth disease (HFMD).

Methods: Among the 100 recruited cases, 56 were in the severe HFMD group (case group) and 44 were in the general HFMD group (control group). By screening functional single nucleotide polymorphisms (SNPS) and hot SNPS, and performing SNP site optimization, some SNP sites of SCARB2 gene were selected for analysis. Genotyping was performed using a MassArray platform. PLINK software was used for statistical processing and analysis of the correlation differences between the mutant genotypes in the severe and general HFMD groups. The relationship between the SNPs and clinical severity of enterovirus (EV)-71 associated HFMD was assessed.
\end{abstract}

Results: 28 SNPs in SCARB2 were selected by site optimization. Then three loci were not in agreement with the minor allele frequency (MAF) in the 1000 Han Chinese in Beijing (CHB) dataset. Another three loci could not be detected. Nine loci were not suitable for further analysis (MAF $<0.01$ and Hardy-Weinberg [HWE] $P<0.001$ ). A total of 13 sites were subsequently analyzed. Through Fisher analysis, the frequency of the rs6812193 T allele was 0.134 and 0.034 in the severe and general HFMD groups, respectively $(P 0.023<0.05$, odds ratio [OR] $4.381>1)$. Logistic regression analysis of rs6812193 T alleles between the severe and general HFMD groups, respectively $(P 0.023<0.05$, OR $4.412>1$, L95 $1.210>1$ ). Genotype logistic regression analysis of the rs6812193 alleles CT+TT versus CC gave an OR of 4.56 (95\% confidence interval [95\% CI] 1.22-17.04, $P=0.012$ ).

Conclusion: The rs6812193 T allele was a susceptibility SNP for SHFMD, and the rs6812193 polymorphism might be significantly associated with the susceptibility to EV-71 infection.

Keywords: Enterovirus 71, Human scavenger receptor B2, Single nucleotide polymorphism, Severe hand-foot-mouth disease

*Correspondence: 250624032@qq.com; 35561411@qq.com 'Xia Wang and Hong Liu have contributed equally to this work Department of Childhood Infectious Diseases, Tianjin Second People's Hospital, Tianjin 300192, China

\section{Introduction}

Hand, foot, and mouth disease (HFMD) is an infectious disease caused by a variety of enteroviruses which belongs to the small RNA virus family [1]. HFMD is common in children under 5 years of age, and it is mainly manifested as herpes and maculopapules on the hands, feet, mouth, and other areas. A few patients progress permits use, sharing, adaptation, distribution and reproduction in any medium or format, as long as you give appropriate credit to the original author(s) and the source, provide a link to the Creative Commons licence, and indicate if changes were made. The images or other third party material in this article are included in the article's Creative Commons licence, unless indicated otherwise in a credit line to the material. If material is not included in the article's Creative Commons licence and your intended use is not permitted by statutory regulation or exceeds the permitted use, you will need to obtain permission directly from the copyright holder. To view a copy of this licence, visit http://creativecommons.org/licenses/by/4.0/. The Creative Commons Public Domain Dedication waiver (http://creativeco mmons.org/publicdomain/zero/1.0/) applies to the data made available in this article, unless otherwise stated in a credit line to the data. 
rapidly and develop neurogenic pulmonary edema, circulatory disturbance, and even death at 1-5 days after disease onset [2]. The following indicators should alert the clinician of possible deterioration and impending critical type of severe case: persistent high fever, nervous system involvement, abnormal respiratory rate and rhythm, circulatory dysfunction, elevated peripheral white blood cell count, elevated blood glucose, elevated blood lactic acid [3]. HFMD is a global disease with a variety of causes. The main causes of HFMD are enterovirus (EV)-71 and Coxsackievirus A16 infection; however, EV-71 is responsible for most of the severe cases and fatal cases [4].

EV-71 is another important neuroenterophilic virus after poliovirus elimination. An analysis shows that EV-71 was circulating in the Netherlands as early as 1963 [5], but it was first reported in 1969 [6]. It was global distribution and occasionally concentrated outbreak. Since 1997, outbreaks of HFMD caused by EV-71 have occurred in the Asia-Pacific region, such as Malaysia [7], Taiwan [8], Singapore [9], etc. In 1998, the epidemic outbreaks began in Chinese mainland, especially in 2007, Shandong province [10] and 2008 Anhui province [11], which resulted in a large number of severe and dead children. Therefore, in 2008, the Ministry of Health of China listed HFMD in the list of Class $\mathrm{C}$ infectious diseases. In recent years, the incidence of HFMD has been 37.01205.06 per 100,000 , with a fatality rate of $6.46-51.00$ per 100,000 [3]. HFMD has the highest number of cases and deaths of all Class $\mathrm{C}$ infectious diseases in China and represents a serious threat to the health of children.

As a major cause of severe and fatal cases, the pathogenesis of EV-71 has attracted more and more researchers' attention. In clinical work, it is not difficult to find that the severity of clinical symptoms and prognosis of different children with the same infection with EV-71 are significantly different. As the first important portal for the virus to enter the human body, the virus receptor determines the host range of a virus and tissue specificity. The influence of individual differences on the severity of clinical symptoms is worth further studying. Yamayoushi et al. [12,13] confirmed that SCARB2 is the receptor of all EV-71 strains in cell experiments. The guidelines for the diagnosis and treatment of HFMD issued by the Ministry of Health of China (2018) clearly indicate that SCARB2 is the main receptor of EV-71 virus. Studies have found that people with different genotypes and alleles have different probability of disease and severity [14]. Single nucleotide polymorphisms (SNPs) are the most common form of variation in human genomic DNA. The SNPs of SCARB2 gene have naturally attracted great attention. At present, most studies focus on the relationship between the severity of EV-71 infection and the polymorphism of cytokines such as TNF-a, IL-6, IL-10 [15, 16], chemokine
IP-10, MCP-1(CCl2) [17], immune-related factors OAS1, OAS2, OAS3 and MXA [18, 19]. To the best of our knowledge, few studies on the relationship between SCARB2 SNP and EV-71 HFMD have been performed. In this study, 28 SNP sites in SCARB2 were selected as study loci, expecting to further clarify the pathogenesis of EV71 infection, and to provide a strong research basis for the early warning of critical disease and the reduction of case fatality rate.

\section{Materials and methods Clinical data and sample collection}

We recruited 100 children with HFMD admitted to our hospital from April 2018 to October 2020 who were positive after EV-71 nucleic acid test. Diagnosis was based on the "Guidelines for the Diagnosis and Treatment of Hand, Foot, and Mouth Disease" (2018) [3]. According to the occurrence and development process of the disease, HFMD is divided into general HFMD and severe HFMD. General HFMD is usually in the eruption stage, but severe HFMD includes nervous system involvement stage, early cardiopulmonary failure stage, and cardiopulmonary failure stage, based on the degree of danger and heavy. There were 56 cases with severe HFMD (as the case group) and 44 cases with general HFMD (as the control group). This study was approved by the Ethics Committee of Tianjin Second People's Hospital, and informed consent was obtained from the patients' parents or family members.

HFMD samples were collected before treatment on the day of admission; $3 \mathrm{~mL}$ peripheral venous blood was collected and stored at $-80^{\circ} \mathrm{C}$ for later use.

\section{SCARB2 SNP selection}

\section{Screening of SNPs}

1. Screening of functional SNPs.

a. In the National Center for Biotechnology Information (NCBI), SNP was searched using the name of the SCARB2 to identify functional SNPs including promoter proxy (upstream variant $2 \mathrm{~KB}$ ), $5^{\prime}$ - untranslated region (UTR), exons (missense, synonymous), 3'-UTR, etc. The relevant optimization parameter was a minor allele frequency (MAF) in Han Chinese in Beijing $(\mathrm{CHB})>0.05$, according to the HapMap or 1000 Genomes databases.

b. The screened SNPs were used for functional prediction.

c. Linkage disequilibrium analysis was performed on the identified SNPs, and the linked sites with $R^{2}=1$ were labeled.

2. Screening of hot SNPs. 
a. Through Google Scholar, the research literature of candidate gene-related polymorphisms was retrieved and susceptibility SNPs were screened out.

b. The screened SNPs were verified using the $\mathrm{CHB}$ MAF values.

\section{SNP site optimization method}

According to the linkage disequilibrium analysis results, the completely linked loci with $\mathrm{R}^{2}=1$ were discarded, and the loci in the promoter region with $R^{2}>0.8$ were retained (Haplotypes in this region are important for gene expression); however, the strong association sites with $R^{2}>0.8$ identified in other regions and literature studies, are meaningless and omitted.

\section{DNA extraction}

DNA was extracted from the blood samples using a Tiangen kit. DNA samples were analyzed on a NanoDrop2000, and $1.25 \%$ agarose gel electrophoresis was performed. DNA was quantified and transferred to a 96-well plate for storage at $-20^{\circ} \mathrm{C}$ for later use.

\section{SNP typing}

\section{Primer design and synthesis}

Assay Designer 3.1 software was used to design the primers, and the primers were synthesized by the company [BGI Tech Solutions (Beijing Liuhe) Co., Ltd]. The primer sequences are shown in Table 1.

\section{Primer dilution and extension mix configuration}

The single-tube PCR masters were diluted to $100 \mu \mathrm{M}$, and deionized water was added to achieve a final PCR master mix concentration of $0.5 \mu \mathrm{M}$. The single tube extension primers were diluted to a final concentration of $500 \mu \mathrm{M}$. Each primer was diluted to $8 \mu \mathrm{M}, 10 \mu \mathrm{M}$, and $15 \mu \mathrm{M}$. According to the instructions of the DNA synthesis products, the molecular weight and number of moles, the amount of deionized water to be added were calculated according to the required concentration. According to the molecular weight of the mixed single-tube extension primers, 1 time (<6300 Da), 1.2 times $(6300-7200 \mathrm{Da})$, and 1.5 times $(>7200 \mathrm{Da})$ were taken for mixing.

\section{MassArray reactions}

PCR amplification was conducted in $5 \mu \mathrm{L}$ reactions, containing $1.000 \mu \mathrm{L}$ DNA $(20 \mathrm{ng} / \mu \mathrm{l}), 1.000 \mu \mathrm{L}$ PCR primers (500 nM each), $0.100 \mu \mathrm{L}$ dNTP mix ( $25 \mathrm{mM}$ each), $0.625 \mu \mathrm{L}$ PCR buffer $(15 \mathrm{mM} \mathrm{MgCl}), 0.325 \mu \mathrm{L} \mathrm{MgCl}_{2}$ $(25 \mathrm{mM}), 1.850 \mu \mathrm{L}$ water HPLC grade, and $0.100 \mu \mathrm{L}$ Taq DNA polymerase $(5 \mathrm{U} / \mu \mathrm{L})$ (Agena Bioscience, San Diego, CA, USA). The PCR conditions were as follows: $94{ }^{\circ} \mathrm{C}$ for $5 \mathrm{~min}, 94{ }^{\circ} \mathrm{C}$ for $20 \mathrm{~s}, 45$ cycles of $56{ }^{\circ} \mathrm{C}$ for $30 \mathrm{~s}, 72{ }^{\circ} \mathrm{C}$ for $1 \mathrm{~min}$, and a final extension step at $72{ }^{\circ} \mathrm{C}$ for $3 \mathrm{~min}$. Remaining unincorporated dNTPs were dephosphorylated and inactivated by treatment with $1 \mathrm{U}$ shrimp alkaline phosphatase at $37^{\circ} \mathrm{C}$ for $20 \mathrm{~min}$ and then $85^{\circ} \mathrm{C}$ for $5 \mathrm{~min}$. Finally, the single base extension reaction mix, including iPLEX Buffer Plus, iPLEX Termination mix, Extension Primers mix, and iPLEX enzyme (Agena Bioscience, San Diego, CA, USA), was added to the PCR amplification products. The single base extension reaction was carried out under the following conditions: $94{ }^{\circ} \mathrm{C}$ for $30 \mathrm{~s}, 40$ cycles at $94{ }^{\circ} \mathrm{C}$ for $5 \mathrm{~s}\left(52{ }^{\circ} \mathrm{C}\right.$ for $5 \mathrm{~s}$ and $80{ }^{\circ} \mathrm{C}$ for $5 \mathrm{~s}$, repeated 5 times per cycle), and a final extension step at $72{ }^{\circ} \mathrm{C}$ for $3 \mathrm{~min}$. The samples were spotted on a SpectroCHIP (Agena Bioscience, San Diego, CA, USA), and analyzed by mass spectrometry. The spectral profiles generated by matrix-assisted laser desorption/ ionization-time of flight mass spectrometry were analyzed using Typer v.4.0 software (Agena Bioscience, San Diego, CA, USA).

\section{Statistical analysis}

PLINK software was used for statistical processing and analysis of the correlation differences between the mutant genotypes in the case and control groups. Case: severe HFMD group; Control: general HFMD group. A1: mutant; A2: wild-type (the default is the variant with the lowest allele frequency). A1 frequency is the MAF value. According to the Hardy-Weinberg equilibrium, the selected samples were from a random population. Fisher test was used to compare the genotype frequency between the case group and the control group. P-value represents the statistical difference between both groups, $P<0.05$ indicates that there is a significant difference in A1 between the case and control groups; OR $<1$ indicates that $\mathrm{A} 1$ is protective; $\mathrm{OR}=1$ indicates that $\mathrm{A} 1$ has no relationship with disease; $\mathrm{OR}>1$ indicates that $\mathrm{A} 1$ has a pathogenic effect. The differences of alleles and genotypes were compared by Logistic regression analysis. 95\% confidence interval $=\mathrm{L} 95-\mathrm{U} 95$. L95 and U95 represent the lower and upper limits of the confidence interval, respectively. OR $>1$ and $L 95>1$ indicate that the allele has a pathogenic effect, while OR $<1$ and $\mathrm{U} 95<1$ indicate that the allele has a protective effect.

\section{Results}

\section{Characteristics}

The characteristics of the subjects are shown in Table 2 . There is no statistically significant difference between the case and control groups in terms of age and sex $(P>0.05)$.

\section{Optimized SNP sites}

The selected 28 SNP sites in SCARB2 were: rs1051326, rs11547135, rs121909118, rs121909119, rs1465922, rs14 
Table 1 Primers used for SNP typing

\begin{tabular}{|c|c|c|c|c|}
\hline SNP ID & 2nd-PCRP & 1st-PCRP & Extension of primers & $\begin{array}{l}\text { Amplified } \\
\text { fragment length } \\
\text { (bp) }\end{array}$ \\
\hline rs1051326 & ACGTTGGATGAGTGAGTGACAGTGAGCTAC & $\begin{array}{l}\text { ACGTTGGATGTATTTCTTCTGGGACAG } \\
\text { CCG }\end{array}$ & GAGGAAGGAACTTGTAAAAA & 127 \\
\hline rs11547135 & ACGTTGGATGAGAGCTGCGCGCACGAACC & $\begin{array}{l}\text { ACGTTGGATGATCCAACTGCAAGG } \\
\text { AGGGAG }\end{array}$ & cccctCGCCGAAGGGTCCCG & 125 \\
\hline rs121909118 & ACGTTGGATGTGACCAGAGTCCACATTCAC & $\begin{array}{l}\text { ACGTTGGATGACTTTATACCGAAAGGC } \\
\text { AGG }\end{array}$ & TTTCAGTGACTATGAGAGTGTA & 129 \\
\hline rs121909119 & ACGTTGGATGGAGATATCGGGCCTGAAAAC & $\begin{array}{l}\text { ACGTTGGATGCAGCAGAAGCTCTT } \\
\text { TGTGAC }\end{array}$ & GATTTCATCTTTGTAGCCC & 118 \\
\hline rs1465922 & $\begin{array}{l}\text { ACGTTGGATGAAGGAAACCGAAACCGA } \\
\text { GTC }\end{array}$ & $\begin{array}{l}\text { ACGTTGGATGTTCGTGCGCGCAGC } \\
\text { TCTGG }\end{array}$ & taCCGGTGCACCCGGGG & 126 \\
\hline rs1465923 & ACGTTGGATGATCCCTAGGTTGCTGCAAAG & $\begin{array}{l}\text { ACGTTGGATGTCCCAGAAGTCTGGCAT } \\
\text { CTC }\end{array}$ & $\operatorname{atgcGCACAGCAGGGATACTAAGGC}$ & 131 \\
\hline rs1470194 & ACGTTGGATGGGTTGGTGTAGGTGAATTAG & $\begin{array}{l}\text { ACGTTGGATGACTGAAGCTTCTACCTC } \\
\text { CTG }\end{array}$ & cccacGTTTACTGGGCCAGCCCAGG & 136 \\
\hline rs200053119 & ACGTTGGATGTCTGCTGTTAGCAACAAGGC & $\begin{array}{l}\text { ACGTTGGATGGCCTACTTACCAATACA } \\
\text { GGA }\end{array}$ & AACAAGGCCTATGTTTTTGAA & 126 \\
\hline rs2119733 & $\begin{array}{l}\text { ACGTTGGATGCAAGTCTGAAACCCAAC } \\
\text { AGG }\end{array}$ & $\begin{array}{l}\text { ACGTTGGATGACCAGTGTGCTCTGGAT } \\
\text { GTG }\end{array}$ & ACAGGGCAGTTATTAAATC & 111 \\
\hline rs2869851 & ACGTTGGATGATGCCAGTCACTGTCCTAAG & $\begin{array}{l}\text { ACGTTGGATGAATACAAGCATGAGCCA } \\
\text { CCG }\end{array}$ & gttgACATATTTACATGTAGTTAATGC & 139 \\
\hline rs3733255 & ACGTTGGATGAAACTGTGTGAGCTGTCCTG & $\begin{array}{l}\text { ACGTTGGATGGGCCAGAATGTTCCTAT } \\
\text { CAC }\end{array}$ & TGTTGAAAGAAGGAAAAAGACAC & 145 \\
\hline rs3733256 & ACGTTGGATGGGCCAGAATGTTCCTATCAC & $\begin{array}{l}\text { ACGTTGGATGAAACTGTGTGAGCTGTC } \\
\text { CTG }\end{array}$ & aTGCAAGGAGGTGGAG & 145 \\
\hline rs57374265 & ACGTTGGATGGTCAGGGTTCATCCATGTTG & $\begin{array}{l}\text { ACGTTGGATGGTGGTATATCTACACAA } \\
\text { CGG }\end{array}$ & CATCCATGTTGTAGCATGTAT & 105 \\
\hline rs6811781 & ACGTTGGATGAGAGAGTCTCACTCTGTCGC & $\begin{array}{l}\text { ACGTTGGATGTGGCTGAGGCAGGA } \\
\text { GAATTG }\end{array}$ & gcttCAACCTCTGCCTCCC & 120 \\
\hline rs6812193 & ACGTTGGATGACTTGATCATGGACTCCACC & $\begin{array}{l}\text { ACGTTGGATGTGCAGTGGTTAATAACA } \\
\text { TGG }\end{array}$ & GGGAAAGCTGGATTTGAA & 112 \\
\hline rs6824953 & ACGTTGGATGTCCCAATGTACTGGAAGCTC & $\begin{array}{l}\text { ACGTTGGATGTAAACCACAGTTGA } \\
\text { AGATG }\end{array}$ & $\begin{array}{l}\text { gggttGGGTGCAGTGACCAAGTC } \\
\text { CTTT }\end{array}$ & 137 \\
\hline rs6841815 & $\begin{array}{l}\text { ACGTTGGATGTGGCTGAGGCAGGAGAA } \\
\text { TTG }\end{array}$ & $\begin{array}{l}\text { ACGTTGGATGAGAGAGTCTCACTCTGT } \\
\text { CGC }\end{array}$ & AGTGAGCCGAGATCA & 120 \\
\hline rs727502772 & ACGTTGGATGTCTGAGTCTGAAAACACCCG & $\begin{array}{l}\text { ACGTTGGATGAGTGAAACGGGAGA } \\
\text { CATTAG }\end{array}$ & TCCGTCTCAGGACTTA & 119 \\
\hline rs727502781 & ACGTTGGATGGGACTACACAGAAATGGTGC & $\begin{array}{l}\text { ACGTTGGATGGATTTGGAACCTCTTGG } \\
\text { CTG }\end{array}$ & gccgTTTCACTTCTCTGATTTGC & 149 \\
\hline rs72857048 & ACGTTGGATGGGAGGAATCCTGTCTTTTAC & $\begin{array}{l}\text { ACGTTGGATGTGATCATGCCACTGCAT } \\
\text { TCC }\end{array}$ & AAGTCTTGCTCTGTTGC & 134 \\
\hline rs75285019 & ACGTTGGATGTAGAGACTGCAGCTACTAAG & $\begin{array}{l}\text { ACGTTGGATGGAGAAGACTCTATCCTA } \\
\text { GGC }\end{array}$ & $\operatorname{tgtTGGAGATCGAAGCTATAAT}$ & 106 \\
\hline rs755903502 & ACGTTGGATGCTCTCTTCTGTGTTTCAGGG & $\begin{array}{l}\text { ACGTTGGATGAGGACAGCTCACAC } \\
\text { AGTTTC }\end{array}$ & gggttTGTTTCAGGGAACAGCGGATG & 118 \\
\hline rs7697073 & ACGTTGGATGATCTGACTCCAAATCTCACG & $\begin{array}{l}\text { ACGTTGGATGTAAGGTGTGATCTTTCT } \\
\text { GGG }\end{array}$ & TCTAATAAAAATAAAGTTGCTATCAC & 124 \\
\hline rs78737354 & ACGTTGGATGATGCCTTGCAACTTCTGCTG & $\begin{array}{l}\text { ACGTTGGATGATGTTCTCTGCAGCAGT } \\
\text { CTC }\end{array}$ & acccGGAGCCTCAAGTCACC & 118 \\
\hline rs886041074 & ACGTTGGATGATGATCTCCCTGAGGAAGTG & $\begin{array}{l}\text { ACGTTGGATGGGGATGCTGCTGTC } \\
\text { TTAATA }\end{array}$ & actgtGACCACTCTATGACAGTC & 100 \\
\hline rs886041076 & ACGTTGGATGGACAGTTACCTTAACTTTAC & $\begin{array}{l}\text { ACGTTGGATGCTGAAAAAATAATTCCA } \\
\text { CTG }\end{array}$ & $\operatorname{tggGGAATGGAATGGGAAAAC}$ & 105 \\
\hline rs886041078 & ACGTTGGATGTTTCTTGCCTCTCCAGAGTG & $\begin{array}{l}\text { ACGTTGGATGGTAGGGTATGTTGG } \\
\text { TGATG }\end{array}$ & AAAGAGACGGCGAGT & 117 \\
\hline rs8475 & ACGTTGGATGCATTTAACTAGATAATTGGGC & $\begin{array}{l}\text { ACGTTGGATGCCTGATAATAGGACTAA } \\
\text { ACC }\end{array}$ & ggggAGATAATTGGGCATGTCTTA & 125 \\
\hline
\end{tabular}


Table 2 Characteristics of the subjects

\begin{tabular}{|c|c|c|c|c|c|c|}
\hline & Characteristics & $n(100)$ & Case & Control & $x^{2}$ & $P$ value \\
\hline \multirow[t]{2}{*}{ Age } & $>3$ years & 36 & 17 & 19 & 1.769 & 0.185 \\
\hline & $\leq 3$ years & 64 & 39 & 25 & & \\
\hline \multirow[t]{2}{*}{ Sex } & Male & 53 & 29 & 24 & 0.075 & 0.784 \\
\hline & Female & 47 & 27 & 20 & & \\
\hline
\end{tabular}

65923, rs1470194, rs200053119, rs2119733, rs2869851, rs3733255, rs3733256, rs57374265, rs6811781, rs6812193, rs6824953, rs6841815, rs727502772, rs727502781, rs728 57048, rs75285019, rs755903502, rs7697073, rs78737354, rs8475, rs886041074, rs886041076, and rs886041078.

Among the 28 optimized sites, the MAFs for rs6811781, rs6841815, and rs72857048, were not in agreement with those in the $1000 \mathrm{CHB}$ dataset, so it was discarded. rs11547135, rs1465922, and rs2869851 could not be detected so that they were excluded from further analysis. Of the 28 SNPs examined, consideration was given to the accuracy of the reaction system and primers. Therefore, SNPs with low detection rates were not used in further analysis. Therefore, a total of 22 SNPs were analyzed further.

The MAFs of the selected SNPs were greater than 0.01 , and the P-values of the Hardy-Weinberg equilibrium test were greater than 0.001. Nine SNPs (rs121909118, rs121909119, rs200053119, rs727502772, rs727502781, rs755903502, rs886041074, rs886041076, and rs886041078) did not fulfill these criteria and were excluded from further analysis. At last, a total of 13 sites were subsequently analysed (Table 3 ).

\section{Fisher analysis}

As shown in Table 4, the frequencies of the rs6812193 T allele was 0.134 and 0.034 in the case and control group, respectively. $P$ value $0.023<0.05$, indicating a significant difference of A1 between the case and control groups; the OR of $4.381>1$ indicates that A1 has a pathogenic effect. The remaining 12 SNPs may not be related to the pathogenicity of EV-71. Therefore, the rs6812193 T genotype is a susceptibility SNP.

\section{Allele logistic regression analysis}

As shown in Table 5, the $P$ value of the rs6812193 T allele was $0.0245<0.05$, indicating a significant difference between the case and control groups; the OR of $4.412>1$ and L95 value $1.210>1$ indicate that the allele had a pathogenic effect. The remaining 12 SNPs may not be related to the pathogenicity of EV-71. Therefore, the rs6812193 T genotype is a susceptibility SNP.

\section{rs6812193 genotype logistic regression analysis}

As shown in Table 6, in the dominant model, the rs6812193 $\mathrm{T}$ allele was associated with a risk of severe disease. $\mathrm{CT}+\mathrm{TT}$ genotype carriers had an increased risk of severe disease compared with $\mathrm{CC}$ genotype carriers $(\mathrm{OR}=4.56,95 \%$ confidence interval $=1.22-17.04$, $P=0.012)$.

\section{Discussion}

The human SCARB2 gene is located on chromosome 4 and encodes a peptide chain containing 478 amino acids. SCARB2 is a transmembrane sialic acid glycoprotein with a relative molecular mass of $85 \mathrm{kDa}$, and belongs to the family of CD36 molecules [20]. SCARB2 is mainly located in lysosomes and endosome, and widely present on the membrane of most human cells including nerve cells [21]. This protein is also called lysosomal integral membrane protein 2 . It is a type of specific glucose cerebral fat enzyme combined with ligands, involved in the lysosomal pathway. The related research fields are mostly Parkinson's disease with abnormal lysosomal metabolism [22, 23], Gaucher's disease and myoclonic epilepsy $[24,25]$. Yamayoshi et al. [12, 13] found that the tissue distribution of EV-71 virus antigen was well correlated with SCARB2, and further found that this receptor was involved in the endocytosis and membrane transport of pathogenic bacteria. This study speculated that the expression level of SCARB2 might be related to virus sensitivity and infection rate. Therefore, the 28 selected sites were all functional sites related to the expression level, including exons, promoters and introns.

Choi $\mathrm{M}$ et al. [26] found that exons contain the vast majority of protein coding synthesis, and about $85 \%$ of pathogenic mutations are located in the exon region. In 2009, Ng SB et al. [27] used exome sequencing for the first time to find point mutations located in MYH3 in 4 patients with Freeman Sheldon syndrome (autosomal dominant genetic disease), showing the powerful effect of exome sequencing in identifying pathogenic genes of Mendelian genetic disease. Many complex diseases have been identified by exome sequencing, such as genetic disease OHDO syndrome (KAT6B) [28], CTNNB1 mutation in craniopharyngioma patients [29], point mutation 
Table 3 Genotyping results

\begin{tabular}{|c|c|c|c|c|c|c|c|c|c|}
\hline & & \multicolumn{2}{|c|}{ Allele N } & \multicolumn{4}{|c|}{ Genotype N (\%) } & \multirow[t]{2}{*}{ MAF (A1) } & \multirow[t]{2}{*}{$\mathrm{H}-\mathrm{W} P$ value } \\
\hline & & A1 & $\mathrm{A} 2$ & & & & Undetected & & \\
\hline \multirow[t]{3}{*}{ rs1051326 } & & C & G & CC 21 & GG 39 & CG 35 & 5 & & \\
\hline & Case & 49 & 59 & 14 & 19 & 21 & 2 & 0.405 & 0.021 \\
\hline & Control & 28 & 54 & 7 & 20 & 14 & 3 & & \\
\hline \multirow[t]{3}{*}{ rs1465923 } & & $C$ & $\mathrm{~T}$ & CCO & TT 92 & TC 8 & & & \\
\hline & Case & 5 & 107 & 0 & 51 & 5 & & 0.040 & 1.000 \\
\hline & Control & 3 & 85 & 0 & 41 & 3 & & & \\
\hline \multirow[t]{3}{*}{ rs1470194 } & & $C$ & A & CC 8 & AA 51 & CA 41 & & & \\
\hline & Case & 31 & 81 & 2 & 27 & 27 & & 0.285 & 1.000 \\
\hline & Control & 26 & 62 & 6 & 24 & 14 & & & \\
\hline \multirow[t]{3}{*}{ rs2119733 } & & A & $\mathrm{T}$ & AA 0 & TT 97 & TA 3 & & & \\
\hline & Case & 2 & 110 & 0 & 54 & 2 & & 0.015 & 1.000 \\
\hline & Control & 1 & 87 & 0 & 43 & 1 & & & \\
\hline \multirow[t]{3}{*}{ rs3733255 } & & $\mathrm{T}$ & C & TT 0 & CC 92 & TC 8 & & & \\
\hline & Case & 6 & 106 & 0 & 50 & 6 & & 0.040 & 1.000 \\
\hline & Control & 2 & 86 & 0 & 42 & 2 & & & \\
\hline \multirow[t]{3}{*}{ rs3733256 } & & $C$ & G & CC 0 & GG 92 & CG 8 & & & \\
\hline & Case & 6 & 106 & 0 & 50 & 6 & & 0.040 & 1.000 \\
\hline & Control & 2 & 86 & 0 & 42 & 2 & & & \\
\hline \multirow[t]{3}{*}{ rs57374265 } & & A & G & AA 13 & GG 36 & GA 51 & & & \\
\hline & Case & 47 & 65 & 8 & 17 & 31 & & 0.385 & 0.529 \\
\hline & Control & 30 & 58 & 5 & 19 & 20 & & & \\
\hline \multirow[t]{3}{*}{ rs6824953 } & & C & G & CC 6 & GG 43 & GC 50 & 1 & & \\
\hline & Case & 31 & 79 & 3 & 27 & 25 & 1 & 0.313 & 0.106 \\
\hline & Control & 31 & 57 & 3 & 16 & 25 & & & \\
\hline \multirow[t]{3}{*}{ rs75285019 } & & A & G & AA 0 & GG 92 & AG 8 & & & \\
\hline & Case & 6 & 106 & 0 & 50 & 6 & & 0.040 & 1.000 \\
\hline & Control & 2 & 86 & 0 & 42 & 2 & & & \\
\hline \multirow[t]{3}{*}{ rs7697073 } & & $C$ & $\mathrm{~T}$ & CC 16 & TT 36 & CТ 48 & & & \\
\hline & Case & 47 & 65 & 11 & 20 & 25 & & 0.400 & 1.000 \\
\hline & Control & 33 & 55 & 5 & 16 & 23 & & & \\
\hline \multirow[t]{3}{*}{ rs 78737354} & & $\mathrm{~T}$ & $C$ & TT 13 & CC 46 & CT 41 & & & \\
\hline & Case & 39 & 73 & 6 & 23 & 27 & & 0.335 & 0.500 \\
\hline & Control & 28 & 60 & 7 & 23 & 14 & & & \\
\hline \multirow[t]{3}{*}{ rs 8475} & & A & $\mathrm{T}$ & AA 13 & ТT 36 & TA 51 & & & \\
\hline & Case & 47 & 65 & 8 & 17 & 31 & & 0.385 & 0.529 \\
\hline & Control & 30 & 58 & 5 & 19 & 20 & & & \\
\hline \multirow[t]{3}{*}{ rs6812193 } & & $\mathrm{T}$ & C & TT 1 & CC 83 & CT 16 & & & \\
\hline & Case & 15 & 97 & 1 & 42 & 13 & & 0.090 & 0.568 \\
\hline & Control & 3 & 85 & 0 & 41 & 3 & & & \\
\hline
\end{tabular}

Undetected: locus detection rate $>95 \%$, which meets the requirements for locus detection

of dilated cardiomyopathy GATAD1 [30], etc. Jenny Do et al. [25] found that 3'-UTR mutations in SCARB2 may be associated with Gaucher disease and myoclonic epilepsy. Yock-Ping Chow et al. [31] found that SCARB2 exon mutation was associated with Pendred syndrome. Yamayoshi et al. [13] found that amino acids at position
142-204 of SCARB2 played an important role in promoting the binding of virus particles to cells and susceptibility to EV-71. However, the study of Ting-Yu Yen et al. did not find the correlation between amino acids at position 142-204 and clinical severity [32]. There are 12 exon sites selected in this study: rs1051326, rs3733255, rs3733256, 
Table 4 Fisher analysis

\begin{tabular}{llllll}
\hline SNP & A1 & FA & FU & P value & OR \\
\hline rs1051326 & C & 0.454 & 0.342 & 0.137 & 1.602 \\
rs1465923 & C & 0.045 & 0.034 & 1.000 & 1.324 \\
rs1470194 & C & 0.277 & 0.296 & 0.875 & 0.913 \\
rs2119733 & A & 0.018 & 0.011 & 1.000 & 1.582 \\
rs3733255 & T & 0.054 & 0.023 & 0.470 & 2.434 \\
rs3733256 & C & 0.054 & 0.023 & 0.470 & 2.434 \\
rs57374265 & A & 0.420 & 0.341 & 0.306 & 1.398 \\
rs6824953 & C & 0.282 & 0.352 & 0.355 & 0.722 \\
rs75285019 & A & 0.054 & 0.023 & 0.470 & 2.434 \\
rs7697073 & C & 0.393 & 0.409 & 0.885 & 0.935 \\
rs78737354 & T & 0.348 & 0.318 & 0.763 & 1.145 \\
rs8475 & A & 0.420 & 0.341 & 0.306 & 1.398 \\
rs6812193 & T & 0.134 & 0.034 & 0.023 & 4.381 \\
\hline
\end{tabular}

FA case group $A 1$ allele frequency, FU control group A1 allele frequency rs6811781, rs6841815, and rs8475 belong to 3' UTR region, and its function was predicted as miRNA binding site. rs11547135 and rs1465922 belong to 5' UTR region, and its function was predicted to be a TFBS transcription factor binding region. rs121909118 rs200053119 rs755903502 and rs886041078 are NCBI pathogenic clinical significance sites. Among these exons, rs6811781 and rs6841815 (not in CHB); rs11547135 and rs1465922 (not detected); rs121909118, rs200053119, rs755903502, rs886041078 (not in line with MAF value). Finally, rs8475, rs1051326, rs3733255 and rs3733256 were included in the study, but no correlation was found between these four exon loci and the severity of clinical infection.

Promoter is an important cis-element in gene expression regulation and the core region of gene transcriptional regulation. In this study, two promoter loci were selected: rs1465923 and rs78737354. Finally, no correlation between these two promoters and clinical infection was found.

Table 5 Allele logistic regression analysis

\begin{tabular}{|c|c|c|c|c|c|c|}
\hline SNP & A1 & L95 & U95 & STAT & $P$ value & OR \\
\hline rs1051326 & $C$ & 0.856 & 2.520 & 1.395 & 0.163 & 1.469 \\
\hline rs1465923 & $C$ & 0.302 & 5.941 & 0.385 & 0.700 & 1.340 \\
\hline rs1470194 & $C$ & 0.491 & 1.695 & -0.291 & 0.771 & 0.912 \\
\hline rs2119733 & A & 0.140 & 18.160 & 0.375 & 0.708 & 1.593 \\
\hline rs3733255 & $\mathrm{T}$ & 0.483 & 13.150 & 1.097 & 0.273 & 2.520 \\
\hline rs3733256 & C & 0.483 & 13.150 & 1.097 & 0.273 & 2.520 \\
\hline rs57374265 & A & 0.784 & 2.651 & 1.176 & 0.240 & 1.441 \\
\hline rs6824953 & $C$ & 0.342 & 1.315 & -1.162 & 0.245 & 0.671 \\
\hline rs75285019 & A & 0.483 & 13.150 & 1.097 & 0.273 & 2.520 \\
\hline rs7697073 & $C$ & 0.529 & 1.652 & -0.233 & 0.816 & 0.935 \\
\hline rs78737354 & $\mathrm{T}$ & 0.640 & 2.009 & 0.430 & 0.668 & 1.134 \\
\hline rs8475 & A & 0.784 & 2.651 & 1.176 & 0.240 & 1.441 \\
\hline rs6812193 & $\mathrm{T}$ & 1.210 & 16.080 & 2.249 & 0.0245 & 4.412 \\
\hline
\end{tabular}

Table 6 rs6812193 genotype logistic regression association with response status $(n=100)$

\begin{tabular}{|c|c|c|c|c|c|}
\hline Model & Genotype & Status $=1$ & Status $=2$ & $\begin{array}{l}\text { OR (95\% confidence } \\
\text { interval = L95-U95) }\end{array}$ & $P$ value \\
\hline \multirow[t]{3}{*}{ Codominant } & $\mathrm{C} / \mathrm{C}$ & 41 (93.2\%) & $42(75 \%)$ & 1 & 0.035 \\
\hline & $\mathrm{C} / \mathrm{T}$ & $3(6.8 \%)$ & $13(23.2 \%)$ & $4.23(1.12-15.95)$ & \\
\hline & $\mathrm{T} / \mathrm{T}$ & $0(0 \%)$ & $1(1.8 \%)$ & NA (0.00-NA) & \\
\hline \multirow[t]{2}{*}{ Dominant } & $\mathrm{C} / \mathrm{C}$ & 41 (93.2\%) & $42(75 \%)$ & 1 & 0.012 \\
\hline & $\mathrm{C} / \mathrm{T}-\mathrm{T} / \mathrm{T}$ & $3(6.8 \%)$ & $14(25 \%)$ & $4.56(1.22-17.04)$ & \\
\hline \multirow[t]{2}{*}{ Recessive } & $\mathrm{C} / \mathrm{C}-\mathrm{C} / \mathrm{T}$ & $44(100 \%)$ & 55 (98.2\%) & 1 & 0.28 \\
\hline & $\mathrm{T} / \mathrm{T}$ & $0(0 \%)$ & $1(1.8 \%)$ & NA (0.00-NA) & \\
\hline \multirow[t]{2}{*}{ Overdominant } & $\mathrm{C} / \mathrm{C}-\mathrm{T} / \mathrm{T}$ & 41 (93.2\%) & $43(76.8 \%)$ & 1 & 0.021 \\
\hline & $\mathrm{C} / \mathrm{T}$ & $3(6.8 \%)$ & $13(23.2 \%)$ & $4.13(1.10-15.56)$ & \\
\hline
\end{tabular}


Previously, it was often believed that introns do not encode proteins and do not have biological functions in organisms. However, studies have found that the expression profiles of the same gene with and without introns are significantly different [33]. In many cases of transgenic expression, the addition of a universal intron to cDNA results in a significant increase in gene expression $[34,35]$. The optimal expression of many endogenous genes has been demonstrated in mammalian tissue culture cells, transgenic mice, insects, and plant systems requiring the presence of one or more introns. Therefore, a variety of introns in organisms are an important part of eukaryotic genome and are closely related to the construction and dynamic changes of cytoskeleton of gene expression [36]. Ting-Yu Yen studied the relationship between SCARB2, PSGL-1, ANXA2 polymorphisms and clinical severity, and found that rs11097262 was associated with rs6824953 located in the intron region of SCARB2 gene, considering that it may regulate the function or expression of SCARB2 and thus affect the susceptibility to EV-71 [32]. In this study, 14 introns were selected: rs121909119, rs727502772, rs727502781, rs886041074, and rs886041076 were considered to be the sites with pathological clinical significance on NCBI website; rs6812193 is a hot spot site that can be found in the literatures [23, 37-39]; rs1470194, rs2119733, rs2869851, rs57374265, rs6824953, rs72857048, rs75285019, and rs7697073 are the TAGSNP sites. Among these introns of this study, rs72857048 is not in CHB; rs2869851 is not detected; rs121909119, rs727502772, rs727502781, rs886041074, and rs886041076 are not in line with MAF value. Finally, rs1470194, rs2119733, rs57374265, rs6812193, rs6824953, rs75285019 and rs7697073 were included in the final study, but only rs6812193 was correlated with the severity of clinical infection, and no correlation was found for the other 6 introns. By using Fisher analysis and allele logistic regression analysis, the rs6812193 $\mathrm{T}$ allele was shown to have a pathogenic effect. rs6812193 genotype logistic regression analysis in a dominant model showed that $\mathrm{CT}+\mathrm{TT}$ genotype carriers had an increased risk of severe HFMD compared with CC genotype carriers. Therefore, the rs6812193 T genotype is considered to be a susceptibility SNP, and the rs6812193 polymorphism may be related to susceptibility to EV-71.

rs6812193 is actually a hot SNP close to SCARB2. A 2011 Web-based Genome-wide Association (GWA) study found that a nucleotide polymorphism rs6812193 close to SCARB2 was significantly associated with Parkinson's disease (PD) in people of European ancestry [37]. In 2012, Shuai Chen et al. conducted a genotyping study on rs6812193 in 449 PD patients and 452 control patients in mainland China, and found that there is no statistically significant differences in allele and genotype distribution between the patients and the control group [38]. In 2013, Kallirhoe Kalinderi et al. studied 210 Greek patients with sporadic PD and 133 control subjects in Greece. It was found that there was no difference in genotype or allele frequency between PD patients and controls [39]. In 2021, T.S. Usenko et al. rs6812193 of the SCARB2 gene does not confer a significant risk for PD in Russian population [23]. At present, to the best of our knowledge, there is no research related to the role of rs6812193 in HFMD. How does rs6812193 affect the expression and function of SCARB2? This will be examined in the future by increasing the sample size to verify the association of rs6812193 with susceptibility to EV-71 HFMD, and to study the function of rs6812193.

The present study also has some limitations, such as the small number of cases, which may make it difficult to find significant differences between low-frequency SNPs. In addition, with sufficient funds and time, genome-wide tests can be performed to avoid screening for missing sites of interest. Clarifying the relationship between gene polymorphisms and disease will enable us to analyze disease pathogenesis further, to explore the nature of the diversity of disease phenotypes, and to develop more individualized treatment measures.

\section{Conclusion}

The rs6812193 $\mathrm{T}$ genotype was identified as a susceptibility SNP. CT + TT genotype carriers have an increased risk of severe HFMD compared with CC genotype carriers. Therefore, the rs6812193 polymorphism might be considerably related to clinical severity of enterovirus (EV)-71 associated HFMD, which can support doctors to make evidence-based health recommendations to patients.

\section{Abbreviations \\ SCARB2: scavenger receptor class B member 2; EV: enterovirus; HFMD: hand-foot-mouth disease; SHFMD: severe hand-foot-mouth disease; SNP: single nucleotide polymorphism; MAF: minor allele frequency; CHB: Han Chinese in Beijing; RNA: ribonucleic acid; DNA: deoxyribonucleic acid; HWE: Hardy-Weinberg; NCBI: National Center for Biotechnology Information; UTR: untranslated region; PCR: polymerase chain reaction; PCRP: polymerase chain reaction primers; HPLC: high performance liquid chromatography; dNTP: deoxy-ribonucleoside triphosphate; A1: mutant; A2: wild-type; FA: case group A1 allele frequency; FU: control group A1 allele frequency; OR: odds ratio; L95: lower limits of the confidence interval; U95: upper limits of the confidence interval; STAT: coefficient t-statistic; MYH3: myosin heavy chain 3; KAT6B: lysine acetyltransferase 6B; GATAD1: GATA zinc finger domain containing 1; TFBS: transcription factor binding site; PSGL-1: P-selectin glycoprotein ligand 1; ANXA2: annexin II; GWA: Genome-wide Association; PD: Parkinson's disease.}

\section{Acknowledgements}

The authors gratefully acknowledge the editors and anonymous reviewers for their valuable comments on this manuscript. 


\section{Authors' contributions}

Conceptualization and methodology, $Y L$ and RS; software and validation, XW and $\mathrm{HL}$; formal analysis, $\mathrm{XW}$; investigation, $\mathrm{XW}, \mathrm{HL}, \mathrm{YL}, \mathrm{RS}, \mathrm{YL}, \mathrm{KQ}$; resources, $Y L$ and $R S$; writing - original draft preparation, $X W$; writing-review and editing, $X W, H L, Y L, R S, Y L, K Q$; supervision, $Y L$ and $R S$; project administration, $Y L$; funding acquisition, $Y L$ and $X W$. All authors read and approved the final manuscript.

\section{Funding}

This research was funded by the Key Project of Tianjin Second People's Hospital (No. YS0019), and the 13th Five-year National Major Project for optimization of prevention and treatment plan for febrile rash syndrome based on HFMD (No. KY0112 2017ZX10103007-002)

\section{Availability of data and materials}

The data used and/or analyzed during this study are available from the corresponding author on request.

\section{Declarations}

\section{Ethics approval and consent to participate}

The study was conducted according to the guidelines of the Declaration of Helsinki, and approved by the Institutional Review Board of Medical Ethics Committee of Tianjin Second People's Hospital (Approval Certificate of Ethical Review No. 201825)

\section{Consent for publication}

No consent for publication applicable. This manuscript does not provide any patients' data nor any animal studies or experiments. This manuscript does not contain any individual person's data in any form. The authors declare no financial and non-financial conflict of interests. This manuscript has not been submitted to, nor is under review at, another journal or other publishing venue. The authors have no affiliation with any organization with a direct or indirect financial interest in the subject matter discussed in the manuscript.

\section{Competing interests}

The authors declare that they have no competing interests.

\section{Received: 13 April 2021 Accepted: 16 June 2021}

Published online: 30 June 2021

\section{References}

1. Solomon T, Lewthwaite P, Perera D, Cardosa MJ, McMinn P, Ooi MH. Virology, epidemiology, pathogenesis, and control of enterovirus71. Lancet Infect Dis. 2010;10:778-90.

2. Ooi MH, Wong SC, Lewthwaite P, Cardosa MJ, Solomon T. Clinical features, diagnosis, and management of enterovirus 71. Lancet Neurol. 2010;9:1097-105

3. Li XW, Ni X, Qian SY, Wang Q, Jiang RM, Xu WB, Zhang YC, Yu GJ, Chen Q, Shang $Y X$, Zhao CS, Yu H, Zhang T, Liu G, Deng HL, Gao J, Ran XG, Yang QZ, Xu BL, Huang XY, Wu XD, Bao YX, Chen YP, Chen ZH, Liu QQ, Lu GP, Liu CF, Wang RB, Zhang GL, Gu F, Xu HM, Li Y, Yang T. Chinese guidelines for the diagnosis and treatment of hand, foot and mouth disease, 2018. World J Pediatr. 2018;14:437-47.

4. Liu SL, Pan H, Liu P, Amer S, Chan TC, Zhan J, Huo XX, Liu YZ, Teng Z, Wang L, Zhuang $H$. Comparative epidemiology and virology of fatal and nonfatal cases of hand, foot and mouth disease in mainland China from 2008 to 2014. Rev Med Virol. 2015;25:115-28.

5. Sanden SVD, Koopmans M, Uslu GK, Avoort HVD. Epidemiology of enterovirus 71 in the Netherlands, 1963 to 2008. J Clin Microbiol. 2009;47:2826-33.

6. Schmidt NJ, Lennette $\mathrm{EH}, \mathrm{Ho} H \mathrm{H}$. An apparently new enterovirus isolated from patients with disease of the central nervous system. J Infect Dis. 1974;129:304-9.

7. Chan LG, Parashar UD, Lye MS, Ong FGL, Zaki SR, Alexander JP, Ho KK, Han LL, Pallansch MA, Suleiman AB, Jegathesan M, Anderson LJ. Deaths of children during an outbreak of hand, foot, and mouth disease in
Sarawak, Malaysia: clinical and pathological characteristics of the disease. Clin Infect Dis. 2000;31:678-83.

8. Ho M, Chen ER, Hsu KH, Twu SJ, Chen KT, Tsai SF, Wang JR, Shih SR. An epidemic of enterovirus 71 infection in Taiwan. New Engl J Med. 1999:341:929-35.

9. Chan KP, Goh KT, Chong CY, Teo ES, Lau G, Ling AE. Epidemic hand, foot and mouth disease caused by human enterovirus 71, Singapore. Emerg Infect Dis. 2003;9:78-85.

10. Zhang Y, Tan XJ, Wang HY, Yan DM, Zhu SL, Wang DY, Ji F, Wang XJ, Gao YJ, Chen L, An HQ, Li DX, Wang SW, Xu AQ, Wang ZJ, Xu WB. An outbreak of hand, foot, and mouth disease associated with subgenotype C4 of human enterovirus 71 in Shandong. China J Clin Virol. 2009:44:262-7.

11. Zhang Y, Zhu Z, Yang WZ, Ren J, Tan XJ, Wang Y, Mao NY, Xu ST, Zhu SL, Cui AL, Zhang Y, Yan DM, Li Q, Dong XP, Zhang J, Zhao YP, Wan JF, Feng ZJ, Sun JL, Wang SW, Li DX, Xu WB. An emerging recombinant human enterovirus 71 responsible for the 2008 outbreak of hand foot and mouth disease in Fuyang city of China. Virol J. 2010;7:94.

12. Yamayoshi S, lizuka S, Yamashita T, Minagawa H, Mizuta K, Okamoto M, Nishimura H, Sanjoh K, Katsushima N, Itagaki T, Nagai Y, Fujii K, Koike S. Human SCARB2-dependent infection by coxsackievirus A7, A14, and A16 and enterovirus71. J Virol. 2012;86:5686-96.

13. Yamayoshi S, Ohka S, Fujii K, Koike S. Functional comparison of SCARB2 and PSGL1 as receptors for enterovirus 71. J Virol. 2013;87:3335-47.

14. LvTG, Li J, Han ZL, Chen ZB. Association of interleukin-17F gene polymorphism with enterovirus 71 encephalitis in patients with hand, foot, and mouth disease. Inflammation. 2013;36:977-81.

15. Yuan AY, Li J, Liu PP, Chen ZB, Hou M, Wang JJ, Han ZL. Association of interleukin -6-572C/G gene polymorphism and serum or cerebrospinal fluid interleukin-6 level with enterovirus 71 encephalitis in Chinese Han patients with hand, foot, and mouth disease. Inflammation. 2015;38:728-35.

16. Zhao N, Chen HL, Chen ZZ, Li J, Chen ZB. IL-10-592 polymorphism is associated with IL-10 expression and severity of enterovirus 71 infection in chinese children. J Clin Virol. 2017;95:42-6.

17. Li JA, Chen ZB, Lv TG, Han ZL. Genetic polymorphism of CCL2-2518, CXCL10-201, IL8+781 and susceptibility to severity of enterovirus-71 infection in a Chinese population. Inflamm Res. 2014;63:549-56.

18. Liu YD, Liu PP, Liu SH, Guo Y, He HF, Yang CQ, Song J, Zhang N, Cheng JG, Chen ZB. Oligoadenylate synthetase 3 S381R gene polymorphism is associated with severity of EV71 infection in Chinese children. J Clin Virol. 2018;101:29-33.

19. Zhang XA, Xu HM, Chen XD, Li XJ, Wang XJ, Ding SJ, Zhang RL, Liu LJ, He C, Zhuang L, Li H, Zhang PH, Yang H, Li TY, Liu W, Cao WC. Association of functional polymorphisms in the MxA gene with susceptibility to enterovirus 71 infection. Hum Genet. 2014;133:187-97.

20. Eskelinen EL, Tanaka Y, Saftig P. At the acidic edge: emerging functions for lysosomal membrane proteins. Trends Cell Biol. 2003;13:137-45.

21. Gonzalez A, Valeiras M, Sidransky E, Tayebi N. Lysosomal integral membrane protein-2: a new player in lysosome-related pathology. Mol Genet Metab. 2014;111:84-91.

22. Michelakakis $H$, Xiromerisiou G, Dardiotis E, Bozi M, Vassilatis D, Kountra PM, Patramani G, Moraitou M, Papadimitriou D, Stamboulis E, Stefanis L, Zintzaras E, Hadjigeorgiou DP. Evidence of an association between the scavenger receptor class B member 2 gene and Parkinson's disease. Mov Disord. 2012;27:400-5.

23. Usenko TS, Bezrukova Al, Bogdanova DA, Kopytova AE, Senkevich KA, Gracheva EV, Timofeeva AA, Miliukhina IV, Zakharova EY, Emelyanov AK, Pchelina SN. Genetics variants and expression of the SCARB2 gene in the pathogenesis of Parkinson's disease in Russia. Neurosci Lett. 2021;741:135509.

24. Mazzulli JR, Xu YH, Sun Y, Knight AL, McLean PJ, Caldwell GA, Sidransky E, Grabowski GA, Krainc D. Gaucher disease glucocerebrosidase and a-synuclein form a bidirectional pathogenic loop in synucleinopathies. Cell. 2011;146:37-52.

25. Do J, Gary S, Stubblefifield B, Ryan E, Lopez G, Sidransky E, Tayebi N. A 3'-UTR variant in SCARB2 modulates LIMP2 in patients with Gaucher disease and myoclonic epilepsy. Abstr Mol Genet and Metab. 2019;126:S49.

26. Choi M, Scholl UI, Ji WZ, Liu TW, Tikhonova IR, Zumbo P, Nayir A, Bakkaloğlu A, Özen S, Sanjad S, Nelson-Williams C, Farhi A, Mane S, Lifton 
RP. Genetic diagnosis by whole exome capture and massively parallel DNA sequencing. Proc Natl Acad Sci USA. 2009;106:19096-101.

27. Ng SB, Turner EH, Robertson PD, Flygare SD, Bigham AW, Lee C, Shaffer T, Wong M, Bhattacharjee A, Eichler EE, Bamshad M, Nickerson DA, Shendure J. Targeted capture and massively parallel sequencing of twelve human exomes. Nature. 2009;461:272-6

28. Clayton-Smith J, O'Sullivan J, Daly S, Bhaskar S, Day R, Anderson B, Voss AK, Thomas T, Biesecker LG, Smith P, Fryer A, Chandler KE, Kerr B, Tassabehji M, Lynch SA, Krajewska-Walasek M, McKee S, Smith J, Sweeney E, Mansour S, Mohammed S, Donnai D, Black G. Whole-exome-sequencing identifies mutations in histone acetyltransferase gene KAT6B in individuals with the Say-Barber-Biesecker variant of Ohdo syndrome. Am J Hum Genet. 2011;89:675-81.

29. Brastianos PK, Taylor-Weiner A, Manley PE, Jones RT, Dias-Santagata D, Thorner AR, Rodriguez FJ, Bernardo LA, Schubert L, Sunkavalli A, Shillingford N, Calicchio ML, Lidov HGW, Taha H, Martinez-Lage M, Santi M, Storm PB, Lee JYK, Palmer JN, Adappa ND, Scott RM, Dunn IF, Laws ER, Stewart C, Ligon KL, Hoang MP, Hummelen PV, Hahn WC, Louis DN, Resnick AC, Kieran MW, Getz G, Santagata S. Exome sequencing identifies BRAF mutations in papillary craniopharyngiomas. Nat Genet. 2014;46:161-5.

30. Theis JL, Sharpe KM, Matsumoto ME, Chai HS, Nair AA, Theis JD, Andrade MD, Wieben ED, Michels VV, Olson TM. Homozygosity mapping and exome sequencing reveal GATAD1 mutation in autosomal recessive dilated cardiomyopathy. Circ Cardiovasc Genet. 2011;4:585-94.

31. Chow YP, Abdul Murad NA, Rani ZM, Khoo JS, Chong PS, Wu LL, Jamal R. Exome sequencing identifies SLC26A4, GJB2, SCARB2 and DUOX2 mutations in 2siblings with Pendred syndrome in a Malaysian family. Orphanet J Rare Dis. 2017;12:40.

32. Yen TY, Shih WL, Huang YC, Lee JT, Huang LM, Chang LY. Polymorphisms in enterovirus 71 receptors associated with susceptibility and clinical Severity. PLoS ONE. 2018;13:e0206769.
33. Nott A, Meislin SH, Moore MJ. A quantitative analysis of intron effects on mammalian gene expression. RNA. 2003;9(5):607-17.

34. Palmiter RD, Sandgren EP, Avarbock MR, Allen DD. Heterologous introns can enhance expression of transgenes in mice. Proc Natl Acad Sci USA. 1991;88:478-82.

35. Bourdon V, Harvey A, Lonsdale DM. Introns and their positions affect the translational activity of mRNA in plant cells. EMBO Rep. 2001;2:394-8.

36. Jeong YM, Mun JH, Lee I, Woo JC, Hong CB, Kim SG. Distinct roles of the first introns on the expression of arabidopsis profilin gene family members. Plant Physiol. 2006;140:196-209.

37. Do CB, Tung JY, Dorfman E, Kiefer AK, Drabant EM, Francke U, Mountain JL, Goldman SM, Tanner CM, Langston JW, Wojcicki A, Eriksson N. Webbased genome-wide association study identifies two novel loci and a substantial genetic component for Parkinson's disease. PLoS Genet. 2011;7:e1002141.

38. Chen S, Zhang Y, Chen W, Wang Y, Liu J, Rong TY, Ma JF, Wang G, Zhang J, Pan J, Xiao Q, Chen SD. Association study of SCARB2 rs6812193 polymorphism with Parkinson's disease in Han Chinese. Neurosci Lett. 2012;516:21-3.

39. Kalinderi K, Bostantjopoulou S, Katsarou Z, Fidani L. Association study of rs6812193 polymorphism with Parkinson's disease in a Greek population. Neurosci Lett. 2013;541:190-2.

\section{Publisher's Note}

Springer Nature remains neutral with regard to jurisdictional claims in published maps and institutional affiliations.
Ready to submit your research? Choose BMC and benefit from:

- fast, convenient online submission

- thorough peer review by experienced researchers in your field

- rapid publication on acceptance

- support for research data, including large and complex data types

- gold Open Access which fosters wider collaboration and increased citations

- maximum visibility for your research: over $100 \mathrm{M}$ website views per year

At BMC, research is always in progress.

Learn more biomedcentral.com/submissions 